\title{
Konservatuvarlarda görev yapan akademisyenlerin tükenmişlik düzeyleri
}

\author{
Serpil Umuzdaş ${ }^{1}$ Funda Keklik Kal ${ }^{2}$ \\ ${ }^{1}$ Tokat Gaziosmanpaşa Üniversitesi, Devlet Konservatuvarı, Tokat, Türkiye \\ sumuzdas@hotmail.com \\ ${ }^{2}$ Tokat Gaziosmanpaşa Üniversitesi, Yüksek Lisans öğrencisi, Tokat, Türkiye \\ Özet
}

Bu çalışmada, konservatuvarlarda görev yapan akademik personelin tükenmişlik düzeylerini çeşitli değişkenlere göre belirlemek amaçlanmıştır. Bu amaçla veri toplama aracı olarak Maslach Tükenmişlik Ölçeği kullanılmıştır. Veriler, Ekim 2017- Şubat 2018 tarihleri arasında elde edilmiştir. Ölçekte; akademisyenlerin yönetim görevinin olup olmaması, meslekte çalışma süresi, görev yaptıkları kurumun bulunduğu şehir gibi demografik bilgiler ve tükenmişlik ile ilgili değerlendirmeyi amaçlayan ifadeler yer almaktadır. Çalışmada, uygun örnekleme yöntemiyle Ankara Gazi Üniversitesi, Afyon Kocatepe Üniversitesi, Tokat Gaziosmanpaşa Üniversitesi, İzmir Ege Üniversitesi konservatuvarları seçilmiştir. Bu kurumlarda görev yapan toplam 138 akademisyenin tamamı çalışmaya dahil edilmiştir. Boş veya eksik yanıtların bulunduğu ölçekler çıkarıldıktan sonra, değerlendirilebilir 56 ölçek elde edilmiştir. Farklılık hesapları Mann whitney u ve Krukal wallis ile yapılmıştır. Dikkat çeken sonuçlar şöyledir: Konservatuvarlarda; yöneticilik yapan akademisyenler yapmayanlara göre daha fazla tükenmișlik yașamaktadır. Duyarsızlaşma boyutunda en fazla doçent doktor unvanlı akademisyenler tükenmişlik yaşamaktadır. Ayrıca, akademisyenlerin görev yaptıkları kurumun bulunduğu şehre göre; en fazla Tokat ilinde ikamet eden akademisyenlerde tükenmişlik yaşandığı sonucuna ulaşılmıștır. Ardında sırasıyla Afyon, Ankara ve İzmir illeri yer almaktadır.

\section{Anahtar kelimeler}

akademisyen, tükenmişlik, konservatuvar

Mesleki olarak, duygularla emek verme işi en çok sanat alanında yapılmaktadır. Sanat yapan ya da eğitimini veren kurumlarda, iş görenlerin duyguları, ürünlerini etkileyecektir. Son ylllarda "tükenmişlik", tüm hizmet alanlarında dikkat çeken, duygulara ilişkin bir fenomen olarak araştırmacılar tarafından ilgi görmüştür. Tükenmişlik, ilk olarak Greene'nin 1961 yllında yayınlanan "A burnout case" (bir tükenmişlik vakası) romanı ile dikkatleri çekmiş, daha sonra insan kaynakları alanında çalışılarak araştırmalara konu olmuştur. ilk kez 1974 yılında Alman psikolog Herbert Freudenberger (1974: 159) tarafından "başarısız olma, yıpranma, enerji ve gücün azalması veya tatmin edilemeyen istekler sonu- cunda bireyin iç kaynaklarında meydana gelen tükenme durumu" şeklinde tanımlanmıştır. Daha açık bir ifade ile kişilerin içsel değerleri nedeni ile kendisini zorlaması ya da aile, iş, değerler sistemi veya toplum gibi dışsal etkenler tarafından zorlanmaları sonucu enerjilerinin, direnç mekanizmalarının ve içsel kaynaklarının tükenmesidir (akt. Umuzdaş, Umuzdaş ve Baş, 2015: 42). Konuyla ilgili en sık kullanılan Maslach Tükenmişlik Envanterini geliştiren Maslach'a göre tükenmişlik "işi gereği yoğun duygusal taleplere maruz kalan ve sürekli diğer insanlarla yüz yüze çalışmak durumunda olan kişilerde görülen fiziksel bitkinlik, uzun süreli yorgunluk çaresizlik ve umutsuzluk duygularının, yapılan işe, hayata ve 
diğer insanlara karşı olumsuz tutumlarla yansıması ile oluşan bir sendrom"dur (Maslach ve Jackson, 1981: 99). Maslach tükenmişliği; duygusal tükenme (emotional exhaustion), duyarsızlaşma (depersonalization) ve düşük kişisel başarı hissi (feeling of reduced personel accomplishment) şeklinde üç boyutlu bir sendrom olarak açıklamıştır (Maslach ve Leiter, 1997).

Duygusal tükenme; tükenmişlik sendromunun en açık şekilde gözlenebilen boyutu olarak kabul edilmektedir. Bu durumu yaşayan kişi aşırı bir yorgunluk, ruhen çökkün duygu durumu, umutsuzluk, bezginlik, bıkkınlık gibi negatif duygusal yüklerle karşılaşabilir. Temelde kişilerin kendilerinden ya da başkalarının yıpranma, enerji kaybı, bitkinlik veya yorgunluklarını ifade etme olarak tanımlanmaktadır.

Duyarsızlaşma; kişiler arası ilişkilerde ortaya çlkar. Bireylerin kendinden ve işinden uzaklaşmaları nedeniyle işe yönelik idealizmlerini ve coşkularını kaybetmeleri, hizmet verilen kişilere aldırış etmemeleri, düşmanlık içeren olumsuz tepkilerde bulunmaları gibi davranış biçimlerini göstermeleri ile ilişkilendirilmektedir. Bu durumu yaşayan bireyler çevrelerindeki insanlara karşı duyarsız olur, kendilerine verilen sorumlulukları yerine getiremezler.

Düşük kişisel başarı hissi; ölçeği geliştirenlere göre diğerlerinden daha karmaşık bir yapıdadır. Duygusal ve fiziksel olarak tükenen, hizmet verdiği insanlara ve kendine yönelik olumsuz bir tutum içine giren kişiler, yaptıkları işlerin gerektirdiği talepleri yerine getirmekte zorlandıklarından kişisel yeterlik duyguları azalmaktadır. Bu anlamda, kişisel başarı duygusunun azalmasının diğer iki yapıyla birlikte görüldüğü kabul edilmektedir (Maslach ve diğerleri, 2001). Tükenmişlik kavramına farklı bir diğer yaklaşımı Oldenberg Tükenmişlik Envanterini geliştiren Demerouti ve arkadaşları getirmiştir. Buna göre tükenmişlik; bitkinlik ve işe duyarsızlaşma olarak ifade edilen iki boyuta indirgenerek işle ilgili negatif deneyimlerin sonucu oluşan bir sendrom olarak tanımlanmaktadır. Bitkinlik boyutu: kişinin içindeki boşluk duygusunu, aşırı iş yükünü, güçlü dinlenme isteğini ve fiziksel bitkinlik durumunu ifade etmektedir. Bunlar iş koşullarının sonucu bireyin uzun ve şiddetli devam eden fiziksel, duygusal ve bilişsel baskılara maruz kalma durumunu göstermektedir. Duyarsızlaşma boyutu: kişinin işinden uzaklaşmasını, işine karşı olumsuz tavır ve davranış göstermesini ifade etmektedir (Demerouti ve diğerleri, 2001).

Tükenmişlik oldukça yaygın görülen ve çalışanların büyük bir çoğunluğunun hayatlarının herhangi bir döneminde karşılaştığı bir sendromdur. Tükenmişlik, yavaş yavaş oluşmakta, bazı faktörlerden beslenerek ortaya çıkmakta ve sonra da kişinin ruhsal dengesini bozarak iş, aile ve sosyal yaşamında önemli izler bırakabilmektedir (Özdemir, Alkan ve Erdem, 2016: 261). Mesleğinden ya da işinden dolayı insanlarla tek yönlü, yani sadece verici bir iletişime girmek zorunda kalan bireyler, verdikleri kadar alamadikları durumlarda, sürekli kendilerinden bir şeyler verdiklerini düşündükçe, bir süre sonra tükendiklerini ve verecek bir şeyleri kalmadığını hissetmeye başlayacaklardır (Maraşlı, 2005: 28).

Bireysel ve örgütsel faktörlerde tükenmeye neden olan özellikler arasındadır. Yaş, medeni durum, çocuk sayısı, işe bağlılık, kişisel beklentiler, güdülenme, kişilik örüntüleri, performans, bireysel yaşantıda karşılaşılan stresler, iş doyumu ve üstlerinden gördüğü destek gibi etmenler, bireysel nedenler başlığı altında ele alınmaktadır. Yapılan işin niteliği, 
icra edilen meslek tipi, çalışma süresi, iş yerinin özellikleri, iş yükünün yoğunluğu, iş gerilimi, rol belirsizliği, eğitim durumu, karara katılamama, örgüt içi ilişkiler, ekonomik ve toplumsal etmenlerin ise tükenmişliğin örgütsel nedenleri olarak ele alındığı görülmektedir (Izgar, 2001: 11).

Aynı zamanda demografik özelliklerdeki farklılıklar da, tükenmişlik üzerinde önemli bir yere sahiptir. Fakat demografik özelliklerden cinsiyet konusundaki araştırmalar pek de tutarlı sonuçlar ortaya koymamıştır. Kimi çalışmalar kadınların erkeklerden daha fazla tükenmişlik durumu yaşadığını ortaya koyarken (Ergin, 1992; Örmen, 1993; Torun, 1997: 48; Sürgevil, 2005: 108), kimileri de erkeklerin kadınlardan daha fazla tükenmişlikle karşı karşıya kaldığını ortaya koymaktadır (Girgin ve Baysal, 2005: 177; Polatcı, Ardıç ve Tınaz, 2007: 9; Otacıoğlu, 2008: 110). Son olarak bazı araştırmalarda ise tükenme açısından erkekler ile kadınlar arasında bir farklılık olmadığı açıklanmaktadır (Naktiyok ve Karabey, 2005; Şanlı, 2006; Gençay, 2007: 772; Polatcı, 2007: 121).

Ayrıca diğer meslek gruplarından da tükenmişlik düzeylerini belirleyen çalışmalar literatürde bulunmaktadır (Ünal, Karlıdağ ve Yoloğlu, 2001; Karahan ve Balat. 2011; Demirkol, 2018). Hekimlere yönelik yapılan bu çalışmada iş doyumu, tükenme ve yaşam doyumunun karşılıklı etkileşim içinde olduğu ve bireyin iş doyumunu arttıracak, tükenmeyi azaltacak girişimlerde bulunulması halinde, yaşam doyumuna ve mutluluğuna katkıda bulunacağı vurgulanmıştır (Ünal, Karlıdağ ve Yoloğlu, 2001).

Özel eğitim okullarında çalışan eğitimcilerin tükenmişlik düzeyleri ve özyeterlilik algılarının çeşitli değişkenlere bağlı olarak incelendiği bu çalışmada; kadın eğitimcilerin kişisel başarılar alt boyutunda kendilerini erkek eğitimcilere göre anlamlı derecede daha tükenmiş olarak gördükleri bulunmuştur. Lisans mezunu olan eğitimcilerin lise mezunu olan eğitimcilere göre kendilerini duygusal tükenme alt boyutunda anlamlı düzeyde daha tükenmiş olarak algıladıkları saptanmıştır. Öğretilebilir öğrencilerle çalışan eğitimcilerin kendilerini otistik öğrencilerle çalışan eğitimcilere göre duygusal tükenme alt boyutumda anlamlı düzeyde daha tükenmiş olarak algıladıkları saptanmıştır. Resmi okullarda çalışan eğitimcilerin kendilerini kişisel başarı alt boyutunda özel okullarda çalışan eğitimcilere göre anlamlı derecede tükenmiş olarak algıladıkları görülmüştür. 11 - 15 yıl kıdeme sahip eğitimcilerin kendilerini 16 yıl ve üstü kıdeme sahip eğitimcilere göre duygusal tükenme alt boyutunda, 1 - 5 yıl, 6 - 10 ve $11-15$ yıl kıdeme sahip eğitimcilerin ise kendilerini 16 yıl ve üstü kıdeme sahip eğitimcilere göre kişisel başarı alt boyutunda anlamlı düzeyde daha tükenmiş olarak alglladıkları saptanmıştır (Karahan ve Balat. 2011).

Muhasebe çalışanları üzerinde yapılan bir diğer çalışmada ise, muhasebe meslek mensupları mesleklerini icra ederken mükellef, mevzuat, maliye (3M) arasında sıkışıp kalmakta, ücretlerini tahsil edememe veya geç tahsil etme, haksız rekabet, meslek itibarının düşme tehlikesi, staja başlamanın sınavla olmasına rağmen meslek mensubu sayısındaki hızlı artış, meslek odalarının sorunları çözmede yetersiz kalması, ara eleman sıkıntısı gibi nedenlerden dolayı zorluklar yaşamaktadırlar. Bu zorluklarla meslek mensubu üzerindeki tükenmişlik baskısının her geçen gün daha da arttığı vurgulanmıştır (Demirkol, 2018).

Akademisyenler ise çağın gerektirdiği hız, rekabet, her geçen gün üzerine eklenerek 
artan bilgi yoğunluğu ve değişim ile çalışmalarını bir baskı altında sürdürmeye devam etmektedirler. Gerek görev yaptıkları kurumun bulunduğu konum itibari ile gerek kurumdaki yöneticilik vasıflarının olması ya da olmaması ile gerekse de unvanlarının kendilerinde oluşturduğu ağır yükler altında faaliyet göstermeye çalışmaktadırlar. Akademik bireyin iş çevresi ile arasında yaşanabilecek en küçük uyumsuzluk, bireyin işe yönelik sahip olduğu enerjiyi, aidiyet ve yeterlilik duygusunu azaltıcı bir etki yaratabilmektedir. Akademik personelin yaşadığı ya da yaşamakta olduğu tükenmişlik durumu, eğitsel ve akademik ürünlere etki edebilecektir. Türkiye'de farklı meslek gruplarına uygulanmış birçok tükenmişlik konulu araştırma mevcut olsa da, araştırıldığı kadarıla, konservatuvarlarda görev yapan akademik personel örnekleminde tükenmişlik ile ilgili hiç çalışma yapılmadığı görülmektedir. $\mathrm{Bu}$ nedenle bu araştırma sonucunda elde edilen bulgular, literatürde yer alarak sonraki çalışmalara yön verebilme açısından önem taşımaktadır.

$\mathrm{Bu}$ çalışma, konservatuvarlarda görev yapan akademik personelin tükenmişlik düzeylerini çeşitli değişkenlere (yönetim görevinin olup olmaması, meslekte çalışma süreleri, görev yaptıkları kurumun bulunduğu şehir) göre ortaya koymak amaçlanmıştır. Alt problemler aşağıdaki gibidir;

1. Konservatuarlarda görev yapan akademisyenlerinin tükenmişlik düzeyleri nedir?

2. Konservatuarlarda görev yapan akademisyenlerinin tükenmişlik düzeyleri, (Duygusal Tükenme, Duyarsızlaşma, Kişisel Başarı alt boyutlarında) akademisyenlerin yönetim görevinin olup olmaması, meslekte çalışma süreleri, görev yaptıkları kurumun bulunduğu şehir de-

ğişkenlerine bağlı olarak farklılaşmakta midır?

\section{Yöntem}

Konservatuvarlarda görev yapan akademisyenlerin tükenmişlik düzeylerinin tespit edilip, çeşitli değişkenlere göre incelendiği bu araştırma betimsel niteliktedir. Uygun örnekleme yöntemiyle seçilen konservatuarlarda görev yapan akademisyenlerin tükenmişlik düzeylerini, var olduğu şekliyle incelemeyi amaçladığından tarama modeli ile çalışılmıştır. Kullanılan yöntemlerin uygunluğu ilgili bilimsel temellere dayanmaktadır (McMillian, 2000).

Çalışmada, Türkiye'deki tüm konservatuvarlar içinden uygun örnekleme yöntemiyle Ankara Gazi Üniversitesi, Afyon Kocatepe Üniversitesi, Tokat Gaziosmanpaşa Üniversitesi, İzmir Ege Üniversitesi konservatuvarları seçilmiştir. Bu kurumlarda görev yapan toplam 138 akademisyenin tamamı çalışmaya dahil edilmiştir. Boş veya eksik yanıtların bulunduğu ölçekler çıkarıldıktan sonra, değerlendirilebilir 56 ölçek elde edilmiştir. Dönüş durumuna ilişkin sayılar aşağıdaki gibidir:

Üniversiteler

Tokat Gaziosmanpaşa Üniversitesi

Afyon Kocatepe Üniversitesi

Ankara Gazi Üniversitesi İzmir Ege Üniversitesi Toplam

\section{Veri toplama aracı}

Konservatuarlarda görev yapan akademisyenlerin tükenmişlik düzeyini ölçmek için Maslach Tükenmişlik Ölçeği (MTÖ) kullanılmıştır. Ölçek, Ergin (1992) tarafından Türkçe'ye uyarlanmış olup 22 ifadeden oluşmaktadır. ifadeler, Duygusal Tükenme (DT), Duyarsızlaşma (D) ve Kişisel Başarıda Düşme (KB) olmak üzere 
3 boyutu kapsamaktadır. Ölçeğin, Cronbach alpha değerinin Duygusal Tükenme Boyutunun 0.90, Duyarsızlaşma boyutunun 0.79, Kişisel Başarıda Düşme boyutunun 0.71 olduğu belirtilmektedir. Orijinal MTÖ, 7'li likert yapıda iken, Türkçe'ye uyarlanırken "hiçbir zaman, nadiren, bazen, çoğu zaman, her zaman" olmak üzere 5 cevap seçeneği kullanılmıştır.

Ölçekte 1, 2, 3, 6, 8, 13, 14, 16, 20 numaralı ifadeler duygusal tükenmişlik, 5, 10, $11,15,22$ numaralı ifadeler duyarsızlaşma, 4, 7, 9, 12, 17, 18, 19, 21 numaralı ifadeler kişisel başarıda azalma boyutuna aittir. Kişisel başarıda azalma alt boyutu ters puanlanmaktadır. Her bir boyutu ayrı olarak değerlendirilen ölçekte; duygusal tükenme ve duyarsızlaşma boyutlarından alınan puanların yüksek, kişisel başarıda düşme boyutundan alınan puanların düşük olması, tükenmişlik durumunun yüksek olduğunu göstermektedir.

\section{Verilerin analizi}

Çalışmada öncelikle tükenmişlik sendromunu oluşturan duygusal tükenme, duyarsızlaşma ve kişisel başarı alt boyutlarına göre akademisyenlerin tükenmişlik düzeyleri belirlenmiştir. Akademisyenlerin yönetim görevinin olup olmaması, meslekte çalışma süreleri, görev yaptıkları kurumun bulunduğu şehir, değişkenlerine göre tükenmişlik düzeylerinin farklılaşıp farklılaşmadığı non-parametrik testlerden Mann whitney u ve Krukal wallis ile analiz edilmiştir. Bu hesaplamalar, ölçeğin her bir alt boyutu için tekrarlanmıştır.

\section{Bulgular}

Tablo 1 incelendiğinde, akademisyenlerin yönetim görevinin olup olmaması değişkenine göre anlamlı bir şekilde farklılaşıp farklılaşmadığını belirlemek üzere yapılan non-parametrik Mann Whitney-U testi sonucunda, bütün alt boyutlarda gruplar arasında yöneticiliği var olan grup lehine istatistiksel açıdan $\mathrm{p}<0.05$ düzeyinde anlamlı bir farklılık saptanmıştır. Yani bütün boyutlarda, yöneticilik yapan akademisyenler yapmayanlara göre daha fazla tükenmişlik yaşadığı söylenebilir. Tablo 2'de, akademisyenlerin unvanlarına göre tükenmişlik düzeylerinin anlamlı bir farklılık gösterip göstermediğini belirlemek amacıyla yapılan Kruskal Wallis-H sonucunda, sadece duyarsızlaşma alt boyutunda grupların sıralama ortalamaları arasındaki fark istatistiksel olarak anlam1ı bulunmuştur (x2=20,231; sd=5; ,001).

$\mathrm{Bu}$ işlemin ardından Kruskal Wallis-H sonrası belirlenen anlamlı farklılığın hangi gruplardan kaynaklandığını belirlemek üzere tamamlayıı karşılaştırma tekniklerine geçilmiştir. Bu amaçla kullanılan özel bir test tekniği bulunmadığından, ikili karşılaştırmalarda tercih edilen Mann Whitney-U uygulanmıştır. Analizler sonucunda duyarsızlaşmanın en fazla Doçent Doktor unvanını taşıyan akademisyenlerde yaşandığı sonucuna ulaşılmıştır.

Tablo 3'de akademisyenlerin çalıştı̆̆ı kurumlara göre tükenmişlik düzeylerine göre anlamlı bir farklılık gösterip göstermediğini belirlemek amacıyla yapılan Kruskal Wallis-H sonucunda, bütün alt boyutların gruplarının sıralamalar ortalamaları arasındaki fark istatistiksel olarak anlamlı bulunmuştur. Farkın kaynaklarına bakıldığında tüm alt boyutlarda en fazla Tokat ilinde ikamet eden akademisyenlerde tükenmişlik yaşandığı sonucuna ulaşılmıştır. Ardında sırasıyla Afyon, Ankara ve İzmir illeri yer almaktadır. 
Tablo 1. Konservatuvarlarda görev yapan akademisyenlerinin yönetim görevinin olup olmamasına göre tükenmişlik düzeyleri

\begin{tabular}{llcccccc} 
& Yöneticilik & $\mathbf{n}$ & S.T. & S.O & U & Z & \\
Duygusal & Var & 12 & 36,12 & 433,50 & 160,500 & $-1,995$ & \multirow{2}{*}{046} \\
Tükenmişlik & Yok & 44 & 25,73 & 1106,50 & & & \\
& Toplam & 56 & & & & & \\
Duyarsızlaşma & Var & 12 & 38,75 & 465,00 & 129,000 & $-2,671$ &, 008 \\
& Yok & 44 & 25,00 & 1075,00 & & & \\
& Toplam & 56 & & & & & \\
Kişisel Başarıda & Var & 12 & 37,17 & 446,00 & 148,000 & $-2,255$ &, 024 \\
Azalma & Yok & 44 & 25,44 & 1094,00 & & & \\
& Toplam & 56 & & & & &
\end{tabular}

Tablo 2. Konservatuvarlarda görev yapan akademisyenlerinin unvanlarına göre tükenmişlik düzeyleri

\begin{tabular}{|c|c|c|c|c|c|c|c|}
\hline & Unvan & $\mathrm{n}$ & $\begin{array}{l}\text { Sira Orta- } \\
\text { laması }\end{array}$ & sd & $\mathrm{x} 2$ & $\mathrm{p}$ & $\begin{array}{c}\text { Anlamlı } \\
\text { Fark }\end{array}$ \\
\hline Duygusal & Okutman & 7 & 15,14 & 5 & 8,973 &, 110 & \\
\hline \multirow[t]{5}{*}{ Tükenmişlik } & Öğr. Gör. & 30 & 30,05 & & & & \\
\hline & Arş. Gör. & 3 & 17,33 & & & & \\
\hline & Yrd. Doç. & 9 & 31,44 & & & & \\
\hline & Doç. Dr. & 6 & 34,17 & & & & \\
\hline & Prof. Dr. & 1 & 48,50 & & & & \\
\hline \multirow{6}{*}{ Duyarsızlaşma } & Okutman(1) & 7 & 11,00 & 5 & 20,231 & ,001 & $1-2,1-4$ \\
\hline & Öğr. Gör.(2) & 30 & 27,98 & & & & $1-5,2-5$ \\
\hline & Arş. Gör.(3) & 3 & 15,00 & & & & $3-4,3-5$ \\
\hline & Yrd. Doc. (4) & 9 & 34,72 & & & & $4-5$ \\
\hline & Doç. Dr.(5) & 6 & 46,83 & & & & \\
\hline & Prof. Dr.(6) & 1 & 41,00 & & & & \\
\hline Kişisel Başarıda & Okutman & 7 & 19,29 & 5 & 8,176 & ,147 & \\
\hline \multirow[t]{5}{*}{ Azalma } & Öğr. Gör. & 30 & 31,17 & & & & \\
\hline & Arş. Gör. & 3 & 14,00 & & & & \\
\hline & Yrd. Doç. & 9 & 26,00 & & & & \\
\hline & Doc. Dr. & 6 & 33,08 & & & & \\
\hline & Prof. Dr. & 1 & 51,50 & & & & \\
\hline
\end{tabular}

Tablo 3. Konservatuvarlarda görev yapan akademisyenlerinin görev yaptıkları kurumun bulunduğu şehre göre tükenmişlik düzeyleri

\begin{tabular}{|c|c|c|c|c|c|c|c|}
\hline & $\begin{array}{l}\text { Çalıştığı } \\
\text { Kurum }\end{array}$ & $\mathrm{n}$ & $\begin{array}{l}\text { Sira Orta- } \\
\text { laması }\end{array}$ & sd & $\mathrm{x} 2$ & $\mathrm{p}$ & $\begin{array}{c}\text { Anlamlı } \\
\text { Fark }\end{array}$ \\
\hline Duygusal & Ankara(1) & 11 & 15,73 & 3 & 18,730 & ,000 & $3-4,1-2$ \\
\hline \multirow[t]{3}{*}{ Tükenmişlik } & Afyon(2) & 8 & 34,94 & & & & \\
\hline & $\operatorname{Izmir}(3)$ & 25 & 25,10 & & & & \\
\hline & Tokat(4) & 12 & 43,00 & & & & \\
\hline \multirow[t]{4}{*}{ Duyarsızlaşma } & Ankara(1) & 11 & 27,68 & 3 & 11,003 & ,012 & $3-4,2-3$ \\
\hline & Afyon(2) & 8 & 36,12 & & & & \\
\hline & $\operatorname{Izmir}(3)$ & 25 & 38,46 & & & & \\
\hline & Tokat(4) & 12 & 21,64 & & & & \\
\hline Kişisel Başarıda & Ankara(1) & 11 & 17,77 & 3 & 21,322 & 000 & $3-4,2-3$ \\
\hline \multirow[t]{3}{*}{ Azalma } & Afyon(2) & 8 & 38,88 & & & & $1-2$ \\
\hline & İzmir|3) & 25 & 22,76 & & & & \\
\hline & Tokat(4) & 12 & 43,38 & & & & \\
\hline
\end{tabular}




\section{Sonuç}

Akademisyenlerin mesleki tükenmişlik düzeyinin incelendiği bu araştırmada; akademisyenlerin tükenmişlik düzeyleri; yönetim görevi, unvan ve kurumun bulunduğu şehre göre farklılık göstermektedir. Akademisyenlerin 12'sinin yönetim görevinin var olduğu, 44 akademisyenin ise yönetim görevinin olmadığı bilinmektedir. Buna göre; akademisyenlerin yönetim görevinin olup olmaması değişkenine göre anlamlı bir şekilde farklılaşıp farklılaşmadığını belirlemek üzere yapılan Mann Whitney-U testi sonucunda, bütün alt boyutlardaki gruplar arasında yöneticiliği var olan grup lehine istatistiksel açıdan $\mathrm{p}<0.05$ düzeyinde anlamlı bir farklılık saptanmıştır. Yöneticilik yapan akademisyenlerin yapmayanlara göre daha fazla tükenmişlik yaşadığı söylenebilir. Araştırmaya 7 okutman, 30 öğretim görevlisi, 3 araştırma görevlisi, 9 yardımcı doçent, 6 doçent doktor ve 1 adet profesör doktorun katıldığı bilinmektedir. Akademisyenlerin unvanlarına göre tükenmişlik düzeylerinin anlamlı bir farklılık gösterip göstermediğini belirlemek amacıyla yapılan Kruskal Wallis-H sonucunda, duyarsızlaşma boyutunda grupların sıralamalar ortalamaları arasındaki fark, istatistiksel olarak anlamlı bulunmuştur. $\mathrm{Bu}$ işlemin ardından Kruskal Wallis-H sonrası belirlenen anlamlı farklılığın hangi gruplardan kaynaklandığını belirlemek üzere tamamlayıcı karşılaştırma yapılmıştır. Buradan; duyarsızlaşmanın en fazla Doçent Doktor unvanını taşıyan akademisyenlerde yaşandığı sonucuna ulaşılmıştır.

Araştırmaya Ankara Gazi Üniversitesinden 11 akademik personel, Afyon Kocatepe Üniversitesinden 8 akademik personel, İzmir Ege Üniversitesinden 25 akademik personel ve Tokat Gaziosmanpaşa Üniversitesinden 12 akademik personelin katılım gösterdiği bilinmektedir. Akademisyenlerin tükenmişlik düzeylerinde görev yaptıkları kurumun bulunduğu şehre göre anlamlı bir farklılık gösterip göstermediğini belirlemek amacıyla yapılan Kruskal Wallis-H sonucunda bütün alt boyutların gruplarının sıralamalar ortalamaları arasındaki fark istatistiksel olarak anlamlı bulunmuştur. Farkın kaynaklarına bakıldığında tüm alt boyutlarda en fazla Tokat ilinde ikamet eden akademisyenlerde tükenmişlik yaşandığı sonucuna ulaşılmıştır. Ardında sırasıyla Afyon, Ankara ve İmir illeri yer almaktadır. Şehirle ilgili bulgular incelendiğinde; konservatuvar akademisyenlerinin en çok ihtiyaç duyduğu; konser, tiyatro, sinema, kütüphane gibi bilimsel ve sanatsal etkinliklerin varlığı ve çeşitliliğine ulaşım imkânlarının bu sonuç ile ilintili olabileceği düşünülmektedir. Bu çalışma; sanat eğitimi kurumu olma özelliğiyle özel olarak seçilerek değerlendirilmiş konservatuvarları örneklem almasıyla bir ilktir. Çalışma önerisi olarak; diğer bölgelerdeki konservatuvarlar ve farklı değişkenlerle çalışılması önerilebilir. Uygulama önerisi olarak ise; bu ve benzer çalışma sonuçlarının eğitsel ve yönetsel düzenlemelerde işe konulmasının gerekliliği dikkat çekmelidir.

\section{Kaynaklar}

Demerouti, E., Bakker, A.B., Nachreiner, F., ve Schaufeli, W.B. (2001). "The Job Demands- Resources Model of Burnout", Journal of Applied Psychology Vol:LXXXVI, s:499-512.

Demirkol, Ö. F. (2018). "Şanlıurfa ilindeki muhasebe meslek mensuplarının tükenmişlik sendromlarının tespitine yönelik bir çalışma", Journal of Current Researches on Social Sciences, 2018, 8 (1), 1938.

Ergin, C. (1992). "Doktor ve Hemşirelerde Tükenmişlik ve Maslach Tükenmişlik Ölçeği'nin Uyarlanması", 7. Ulusal Psikoloji Kongresi Bilimsel Çalışmalan, Ha- 
cettepe Üniversitesi, Editörler: R. Bayraktar ve i. Dağ, Ankara, s. 143 - 154.

Freudenberger, H. J. (1974). "Staff Burnout", Journal of Social Issues, Vol. 30, pp. $159-165$.

Gençay, Ö. A. (2007). "Beden Eğitimi Öğretmenlerinin iş Doyumu Ve Mesleki Tükenmişliklerinin Bazı Değişkenler Açısından İncelenmesi", Kastamonu Eğ $i$ tim Dergisi, 15 (2), s. 765 - 780.

Girgin, G. ve Baysal, A. (2005). "Tükenmişlik Sendromuna Bir Örnek: Zihinsel Engelli Öğrencilere Eğitim Veren Öğretmenlerin Mesleki Tükenmişlik Düze$y i^{\prime \prime}$, TSK Koruyucu Hekimlik Bülteni, 4 (4), s. $172-187$.

Izgar, H. (2001). "Okul Yöneticilerinde Tükenmişlik", Nobel Yayın Dağıtım, Ankara.

Karahan, ş. ve Balat, U. G. (2011). “Özel Eğitim Okullarında Çalışan Eğitimcilerin Öz-Yeterlik Algılarının ve Tükenmişlik Düzeylerinin İncelenmesi", Pamukkale Üniversitesi Eğitim Fakültesi Dergisi, Sayı 29 (Ocak 2011/I), s. 1-14.

Maraşlı, M. (2005). "Bazı Özelliklerine ve Öğrenilmiş Güçlülük Düzeylerine Göre Lise Öğretmenlerinin Tükenmişlik Düzeyleri", TTB Mesleki Sağlık ve Güvenlik Dergisi, Temmuz - Eylül, s. 27-33.

Maslach, C. ve Jackson, S. E. (1981). "The Measurement of Experienced Burnout", Journal of Occupational Behaviour, Vol: 2, 99-113.

Maslach, C. ve Leiter, M. P. (1997). "The Truth About Burnout" . San Francisco, CA: Lossey-Bass.

Maslach, C., Schaufeli, W.B. ve Leiter, M.P., (2001). "Job Burnout", Annual Review Psychology, Vol:LII: 397-422.
McMillan, J. H. (2000). Educational research, Fundamentals for the consumer, Longman, USA.

Naktiyok, A. ve Karabey, C. N. (2005). "Işsoliklik ve Tükenmişlik Sendromu", Atatürk Üniversitesi iktisadi ve idari Bilimler Fakültesi Dergisi, 19/1).

Otacıoğlu, S. G. (2008). "Müzik Öğretmenlerinde Tükenmişlik Sendromu Ve Etkileyen Faktörler", inönü Üniversitesi Eğitim Fakültesi Dergisi, 9 (15), s. 103 116.

Örmen, U. (1993). "Tükenmişlik Duygusu ve Yöneticiler Üzerinde Bir Uygulama", Yayınlanmamış Yüksek Lisans Tezi, Marmara Üniversitesi, İstanbul.

Özdemir, S., Alkan, A. ve Erdem, R. (2016). "işs yaşamında yalnızlık ile mesleki tükenmişlik arasındaki ilişki: akademisyenler üzerine bir araştırma", Süleyman Demirel Üniversitesi Sosyal Bilimler Enstitüsü Dergisi Yıl: 2016 Sayı: CiEP Özel Sayısı, s. 261.

Polatcı, S. (2007). "Tükenmişlik Sendromu Ve Tükenmişlik Sendromuna Etki Eden Faktörler /Gaziosmanpaşa Üniversitesi Akademik Personeli Üzerinde Bir Analiz)", Gaziosmanpaşa Üniversitesi, Sosyal Bilimler Enstitüsü, Yayınlanmamış Yüksek Lisans Tezi, Tokat.

Polatcı, S., Ardıç, K. ve Tınaz, Z. D. (2007), "Tükenmişlik Sendromu Ve Demografik Özelliklerin Tükenmişlik Üzerine Etkisi: Tokat Orta Öğretim Kurumlarında Bir Analiz", Sosyal Ve Ekonomik Araştırmalar Dergisi, Emin Kayar Özel Sayısı, Vol. 7, s. $1-22$.

Sürgevil, O. (2005). "Tükenmişlik Ve Tükenmişliği Etkileyen Örgütsel Faktörler: Akademik Personel Üzerinde Bir Uygulama", Dokuz Eylül Üniversitesi, Sosyal Bilimler Enstitüsü, Yayınlanmamış Yüksek Lisans Tezi, İzmir. 
Şanlı, S. (2006). "Adana ilinde Çalişan Polislerin iş Doyumu Ve Tükenmişlik Düzeylerinin Bazı Değişkenler Açısından incelenmesi", Yayınlanmamış Yüksek Lisans Tezi, Çukurova Üniversitesi, Sosyal Bilimler Enstitüsü, Adana.

Torun, A. (1997). "Stres ve Tükenmişlik", Endüstri ve Örgüt Psikolojisi-2. Baskı, Editör: Suna Tevrüz, Türk Psikologlar Derneği ve Kalder Derneği Ortak Yayını, istanbul.
Umuzdaş, S., Umuzdaş, M. S., ve Baş, H. (2015). "ilköğretim müzik öğretmenlerinin tükenmişlik düzeylerinin incelenmesi" , Akademik Sosyal Araştırmalar Dergisi, Yıl: 3, Sayı: 15, Eylül 2015, s. 41-53.

Ünal, S., Karlıdă̆, R. ve Yoloğlu, S. (2001). "Hekimlerde Tükenmişlik ve iş Doyumu Düzeylerinin Yaşam Doyumu Düzeyleri ile ilişkisi", Klinik Psikiyatri 2001;4:113-118. 


\section{Burnout levels of academicians working in conservatories}

\section{Extended abstract}

Occupationally, emotional labor is mostly done in the field of art. In the institutions that make or teach art, the feelings of those who work will affect their products. In recent years, "burnout" has attracted researchers as a phenomenon related to emotions that attract attention in all service areas. According to Maslach, who developed Maslach Burnout Inventory which is the most frequently used inventory in the field, "burnout is a syndrome characterized by physical exhaustion, long-term fatigue, desperation and despair feelings in people who are exposed to intense emotional demands for work and who constantly have to face with other people" (Maslach and Jackson, 1981: 99|. The burnout situation which academic staff experiences can influence educational and academic products. Although there are a lot of researches on burnout on different occupational groups in Turkey, as far as investigated, there is no study made regarding the burnout in the sample of academic staff working in the conservatory. Therefore, the findings of this research are important in terms of being able to take part in the literature and to guide the next studies.

This study, in which exhaustion levels of academicians working at conservatories are determined and analyzed according to various variants, is a descriptive study. The aim was to examine the burnout levels of the academicians working in the selected conservatories with the appropriate sampling method. In this study, conservatories of Ankara Gazi University, Afyon Kocatepe University, Tokat Gaziosmanpasa University, Izmir Ege University were selected with the appropriate sampling method from all conservatories in Turkey. A total of 138 academicians working at these institutions were included in the study. After eliminating the scales with empty or incomplete answers, 56 scales to be evaluated were obtained.

As a result, in this study which the levels of occupational burnout of academicians were examined, it was observed that the burnout levels of academicians differ according to administrative duty, title and the city where the institution is located. It is known that 12 of the academicians have administrative duties and 44 academicians do not have administrative duties. According to this; as a result of the Mann Whitney-U test, which was conducted to determine whether the academicians differed in terms of whether they had an administrative duty, it was determined that there was a statistically significant difference among the groups in all subdimensions respectively on $\mathrm{p}<0.05$ level. It can be said that academicians who are administrators experienced more burnout than those who are not. It is known that 7 apprentices, 30 lecturers, 3 research assistants, 9 assistant professors, 6 associate professors and 1 professor participated in the research. The Kruskal Wallis-H result, which was used to determine whether there was a significant difference in exhaustion levels according to the titles of academicians, was found to be statistically significant in terms of the order of groups in the dimension of desensitization. Complementary comparisons were then made to determine which groups resulted in a significant difference after Kruskal Wallis-H. It is concluded that; the desensitization is most experienced by academicians bearing the title of Associate Professor. It is known that 11 academic staff from Ankara Gazi University, 8 academic staff from Afyon Kocatepe University, 25 academic staff from Izmir Ege University and 12 academic staff from Tokat Gaziosmanpasa University participated in the research. As a result of Kruskal Wallis-H, which was established in order to determine whether the academicians had a significant difference according to the city where they were working at the burnout level, the difference among ranking averages of groups from all sub-dimensions was found to be significantly meaningful. When we look at the sources of the difference, in all the sub-dimensions, it is concluded that academicians residing in Tokat province experienced burnout the most. Afyon, Ankara, and Izmir are next on the list respectively. This work is the first of its kind because of its sampling method to specially select Conservatories and evaluate them as being an arts education institution. As a study recom- 
mendation; it can be suggested that conservatories in other regions can be studied with different variables. As an application proposal; it should be noted that this and similar work outcomes must be put into practice in educational and administrative arrangements.

\section{Keywords}

academicians, burnout, conservatory 